Revista Universo Contábil, ISSN 1809-3337
Blumenau, v. 14, n. 2, p. 118-136, abr./jun., 2018
doi:10.4270/ruc.2018214
Disponivel em www.furb.br/universocontabil

\title{
CASH HOLDINGS IN BRAZIL: A STUDY CONSIDERING THE EFFECTS OF FINANCIAL CONSTRAINTS AND THE ADOPTION OF INTERNATIONAL FINANCIAL REPORTING STANDARDS ${ }^{1}$
}

\author{
GESTÃO DOS SALDOS DE CAIXA NO BRASIL: UM ESTUDO \\ CONSIDERANDO OS EFEITOS DAS RESTRIÇÕES FINANCEIRAS E DA ADOÇÃO \\ DE NORMAS INTERNACIONAIS DE CONTABILIDADE
}

\section{GESTIÓN DEL EFECTIVO EN BRASIL: UN ESTUDIO CONSIDERANDO LOS EFECTOS DE LAS RESTRICIONES FINANCIERAS Y DE LA ADOPCIÓN DE LAS NORMAS INTERNACIONALES DE CONTABILIDAD}

\author{
Aviner Augusto Silva Manoel \\ $\mathrm{PhD}$ Candidate in Controllership and Accounting of University of São Paulo \\ Address: Av. dos Bandeirantes 3900 FEA-RP \\ ZIP: 14040-905 - Ribeirão Preto - SP - Brazil \\ Email: aviner@usp.br \\ Phone: 55 (16) 9-9229-9405

\begin{abstract}
Marcelo Botelho da Costa Moraes
Professor at Accounting Department University of São Paulo Address: Av. dos Bandeirantes 3900 FEA-RP ZIP: 14040-905 - Ribeirão Preto - SP - Brazil Email: mbotelho@usp.br Phone: 55 (16) 3315-9015
\end{abstract}

\begin{abstract}
Firms use of internal and external sources to finance their activities. However, in the presence of imperfections in capital market, such as information asymmetry, agency problems and transaction costs, they may opt for one over another. In this sense, evidence obtained from previous studies suggests that cash holdings are more valuable for restricted companies than for unrestricted ones. Furthermore, the IFRS adoption is one of the most important subjects in recent accounting history. We analyze, in this article, the effects of financial constraints and the IFRS adoption on cash management in Brazil. For that, we used the Generalized Method of Moments (GMM) by dynamic panel data in order to explicitly consider the problems of endogeneity. The sample used comprises 219 public firms from 2000 to 2017. Our results indicate that, on average, the cash management of firms is influenced by its level of financial

\footnotetext{
${ }^{1}$ Artigo recebido em 25/01/2018. Revisado por pares em 31/10/2018. Reformulado em 25/11/2018. Recomendado para publicação em 28/11/2018 por Tarcísio Pedro da Silva. Publicado em 20/02/2019. Organização responsável pelo periódico: FURB.
} 
constraint. Financially constrained firms by size criteria and dividend-paying hold more cash than the smaller ones and non-dividend paying firms, respectively. We also verify a significant reduction in cash levels after the mandatory adoption of IFRS. Finally, our results reveal that firms' leverage, profitability, growth opportunities, current liquidity, net working capital and short-term debt are important in determining cash holdings in Brazil.

Keywords: Cash Holdings, IFRS, Financial Crisis.

\section{RESUMO}

As organizações, para financiar suas atividades, fazem uso de fontes internas e externas. Entretanto, na presença de imperfeições no mercado de capitais, como assimetria de informações, problemas de agência e custos de transação, elas podem optar por uma em detrimento a outra. Neste sentido, evidências obtidas por estudos anteriores sugerem que as reservas em caixa são mais valiosas para as empresas restritas do que para as irrestritas. Além do mais, a adoção das IFRS é uma das questões mais importantes da história da contabilidade. Neste caminho, nós analisamos neste artigo os efeitos das restrições financeiras e da adoção das IFRS sobre a gestão do caixa no Brasil. Para tanto, nós utilizamos o Método dos Momentos Generalizados para dados em painel no intuito de considerar explicitamente os problemas de endogeneidade. A amostra utilizada contempla 219 empresas de capital aberto entre 2000 e 2017. Nossos resultados indicaram que, na média, a gestão do caixa das empresas é influenciada pelo seu nível de restrição financeira. De modo que, as empresas financeiramente restritas pelo fator tamanho e as empresas pagadoras de dividendos mantêm níveis maiores de caixa do que as de menor porte e do que as não pagadoras de dividendos, respectivamente. Nós também verificamos uma redução significativa nos níveis de caixa após a adoção obrigatória das IFRS. Por fim, nossos resultados apontam que a alavancagem, rentabilidade, oportunidades de crescimento, liquidez corrente, capital circulante líquido e endividamento de curto prazo das empresas são importantes para determinar as reservas de caixa no Brasil.

Palavras-Chave: Saldo de Caixa, IFRS, Crise Financeira.

\section{RESUMEN}

Las organizaciones, para financiar sus actividades, hacen uso de fuentes internas y externas. Sin embargo, en presencia de imperfecciones en el mercado de capitales, como asimetría de informaciones, problemas de agencia y costos de transacción, ellas pueden optar por una en detrimento a otra. En este sentido, evidencias obtenidas por estudios anteriores sugieren que las reservas de efectivo son más valiosas para las empresas restringidas que para las irrestrictas. Además, la adopción de las Normas Internacionales de Contabilidad (NIC) es una de las cuestiones más importantes de la historia de la contabilidad. En este camino, analizamos en este artículo los efectos de las restricciones financieras y de la adopción de las NIC sobre las políticas de efectivo en Brasil. Para ello, utilizamos el Método de los Momentos Generalizados para datos en panel con el fin de considerar explícitamente los problemas de endogeneidad. La muestra utilizada contempla 219 empresas de capital abierto entre 2000 y 2017. Nuestros resultados indican que, en promedio, la gestión de efectivo está influenciada por su nivel de restricción financiera. De modo que las empresas financieramente restringidas por el factor tamaño y las empresas pagadoras de dividendos mantienen niveles mayores de efectivo que las de menor porte y que las firmas no pagadoras de dividendos, respectivamente. También verificamos una reducción significativa en los niveles de efectivo después de la adopción obligatoria de las NIC. Por último, nuestros resultados apuntan que el apalancamiento, rentabilidad, oportunidades de crecimiento, liquidez corriente, capital circulante neto y endeudamiento a corto plazo de las empresas son importantes para determinar las reservas de efectivo en Brasil. 
Palabras clave: Tenencias de Efectivo, NIIF, Crisis Financiera.

\section{INTRODUCTION}

One of the most important financial decisions for organizations is about the amount of total assets to be allocated in cash and cash equivalents (GAO; HARFORD; LI, 2013). The decision to keep higher or lower levels of cash holdings is basically an investment decision (KEYNES, 1936). After the seminal works of Keynes (1936), Baumol (1952) and Miller and Orr (1966) numerous studies have examined the determinants of cash holdings over the last few years, see Opler et al. (1999), Harford (1999), Dittmar, Mahrt-Smith and Servaes (2003), Almeida, Campello and Weisbach (2004), Ferreira and Vilela (2004), Han and Qiu (2007), Bates, Kahle and Stulz (2009), Pinkowitz, Williamson and Stulz (2016), Manoel et al. (2017), Manoel et al. (2018) among others.

According to Modigliani and Miller (1958), an organization's investment decisions are not affected by its financing decisions. The authors' theory, however, was built on the premise of a perfect market, which in turn are platonic abstractions, given that there are no transaction costs, information asymmetry and agency problems, as well as unlimited access to credit at a risk-free interest rate.

In view of this, external finance would be considered perfect substitutes for internal finance (DENIS; SIBILKOV, 2010) and a firm's cash reserves are a sideshow to its investment and financing decisions (KEYNES, 1936; AMESS; BANERJI; LAMPOUSIS, 2015). However, the imperfections of the capital markets, such as asymmetric information, agency problems and transaction costs imply that organizations opt to use internal sources over the external ones (JENSEN, 1986; JENSEN; MECKLING, 1976; MYERS; MAJLUF, 1984; FAZZARI; HUBBARD; PETERSEN, 1988). In this case, it is also expected that internal cash flows play a more relevant role in investments of these organizations (KADAPAKKAM; KUMAR; RIDDICK, 1998).

Under the limitations of an imperfect market, organizations are forced to postpone or even depart valuable projects when internal capital are insufficient and there is no compatible way to obtain resources at an affordable cost that does not make the project unfeasible. Thus, in order to circumvent these adverse effects, organizations may choose to allocate part of their cash flows to their cash reserves (DENIS; SIBILKOV, 2010; DAHROUGE; SAITO, 2013).

In times of crisis, when there is a reduction in credit availability, increased uncertainties and a lack of confidence in the market, the effects of financial constraints on organizations' investments and in their cash policies may be even greater (GAO; HARFORD; LI 2013). An investment decision will depend directly on an organization's cash holdings and the availability of affordable financing. Consequently, the existence of financial constraints is a key variable in understanding a firm's investment decisions (LÓPEZ-GUTIÉRREZ; SANFILIPPO-AZOFRA; TORRE-OLMO, 2015) and determining a firm's cash holdings (LEE; PARK, 2016)

In addition, market imperfections are more serious in countries considered as emerging, such as the Brazilian case and other Latin American countries (CAMPELLO, 2012). The Brazilian economy, characterized by high inflation and interest rates (KIRCH; PROCIANOY; TERRA, 2014) may affect even more the cash management of organizations, given the greater contraction of consumption and reduced investment opportunities, especially in crisis contexts. In such scenarios, the amount held in cash by organizations is a controversial subject of great attention to managers (DAHROUGE; SAITO, 2013). Therefore, Brazilian companies, located in an incipient market when compared to U.S. and European market, should suffer even more the consequences of financial obstacles.

Furthermore, the recent change in accounting standards around the world to International Financial Reporting Standards (IFRS) is also likely to have an impact on the 
organizations' cash policies. The theoretical assumptions found in the literature so far indicate this may occur because of IFRS adoption can provide a higher liquidity, lower capital cost and information asymmetry, and greater market attractiveness (DASKE et al., 2008; BALL; LI; SHIVAKUMAR, 2015).

Currently mandatory in approximately 150 countries, according to the IFRS Foundation (2017), the effects and consequences of these changes are subject of debates and studies by researchers and professionals, given that the accounting standards change that result from IFRS is one of the most important issues in accounting history (DASKE et al., 2008). Thus, in an environment where information is asymmetric, the capital market is imperfect and access to credit is restricted, we focus on this research question:

What are the impacts of financial constraints and the IFRS adoption on cash holdings of Brazilian public firms?

To answer this question, this study has the following objectives: analyze the effects of the Financial Constraints, also considering the Subprime Financial Crisis, on the cash holdings, as well as the impacts of the adoption of IFRS.

The motivation for this paper lies in the fact that the study of cash levels represents a strategy of risk management, and can be a source of differentiation, especially in times of economic recession and contexts where access to credit is restricted. Luo (2011) mentions that financial constraints can also favor a more conscious use of companies' cash reserves, since managers should be more assertive in choosing the firm's investment projects given the limited resources available. We expect, therefore, to contribute to managers in the completely decisionmaking process on the strategic management of cash, especially in a context, according to Lozano and Caltabiano (2014), of low access to credit and higher cost of external capital.

In addition, the form of division between constrained and unconstrained firms is a little in-depth topic in Brazil, which also allows us to contribute to the understanding of cash management within each group, since financial constraints represent a relevant topic in managers' decision-making process. The way which financial constraints affect each economic group is a central question (FARRE-MENSA; LJUNGQVIST, 2016).

Articles about the economic consequences of IFRS adoption are relevant given that IFRS are increasingly accepted in the world (AHMED; CHALMERS; KHLIF, 2013). Thus, we also contribute to the literature by pointing out that Brazilian public companies showed a tendency to reduce their cash levels in recent years, especially after the IFRS adoption. This result, in turn, is contrary to the trend of increased cash holdings around the world since the late 1990s, as pointed out by Pinkowitz, Williamson and Stulz (2016).

To test the impact of financial constraint on cash holdings we classify firm-years into constrained and unconstrained based on three proxies: Dividends, Size and Age. For that, we used a sample of 219 Brazilian public firms from 2000 to 2017.

Overall, the results obtained indicate that, on average, the cash management of firms is influenced by its level of financial constraint. Financially constrained firms by size criteria tend to hold more cash than the unconstrained ones. In addition, dividend-paying companies hold more cash than non-dividend paying firms.

Our study supports the view that financially constrained organizations hold more cash than unconstrained firms. Moreover, we find that cash holdings decrease significantly with the IFRS adoption, net working capital and short-term debt. Finally, cash holdings increase significantly with leverage, growth opportunities, profitability and current liquidity.

The rest of the paper is organized as follows. First, the two hypotheses of research are developed. In sequence, we describe the research methodology and the sample used. Finally, in the last two sections we present the empirical results and the final considerations. 


\section{DEVELOPMENT OF THE HYPOTHESIS}

\subsection{Financial Constraints}

Beck et al. (2006) defines a financially constrained company if a windfall increase in the supply of internal finance results in a higher level of investment spending. In other words, a firm is financially unconstrained, according to Han and Qiu (2007), if it has enough financing capacity to make the first-best investments, either now or in the future, regardless of the realization of future cash flow. A financially constrained firm, in turn, does not have enough financing capacity to make the first-best investments (HAN; QIU, 2007).

Because of financial constraints, not all organizations can rely on debt to finance their activities, since that external funds is more costly than internal finance. The lack of available cash, for example, can result in loss of investment opportunities. The excess of cash, on the other hand, results in idle money and resources with low profitability (ALMEIDA; CAMPELLO; WEISBACH, 2004).

Hence, financially constrained companies choose their optimal cash levels to balance the profitability of current and future investments (ALMEIDA; CAMPELLO; WEISBACH, 2004). Larger the credit constraints of an organization then greater the value of cash for it (LYANDRES, 2007). Financial constraints also lead organizations to have a precautionary motive for cash (KEYNES, 1936; OPLER et al., 1999). This demand is a function of the unpredictability of a company's cash flows and in the face of an investment opportunity, the lack of capital would make some investment impossible, given the higher cost of outside capital relative to internally generated funds (DENIS; SIBILKOV, 2010). Taking all these points into consideration, Gao, Harford and $\mathrm{Li}$ (2013) provide evidence that precautionary motives and credit constraints are clearly trivial factors in cash management.

A positive NPV (Net Present Value) project will be financed by internal finance aiming to avoid the agency costs associated with debt and equity, as well as the problem of underinvestment (WEIDEMANN, 2017). Thus, organizations with financial frictions adjust their cash policies to mitigate these constraints, for example by allocating future cash flows to increase net working capital, cash and short-term investments (ALMEIDA; CAMPELLO; WEISBACH, 2004; DITTMAR; MAHRT-SMITH; SERVAES, 2003; OZKAN; OZKAN, 2004).

Kaplan and Zingales (1997) consider that in addition to internal funds, the level of financial constraints also regulates an organization's level of investment. Kadapakkam, Kumar, and Riddick (1998) complement by showing that a firm's corporate investments are affected by the availability of internal funds, which in turn, can mitigate the consequences of a future financing constraint.

A financially unconstrained firm has no precautionary motive for cash. However, a restricted firm will not be able to make new investments in the future without saving resources or reducing current investments (HAN; QIU, 2007). Finally, in times of crisis, Campello, Graham and Harvey (2010) provide evidence that even the most experienced companies had difficulties to initiate or renew credit lines.

Therefore, since that greater cash reserves might be more valuable to restricted firms (DENIS; SIBILKOV, 2010), we expect that constrained firms keep larger percentages of their assets in cash than the unrestricted ones. Given all the above, the first hypothesis of this study is:

H1. Firms with higher (lower) levels of financial constraints maintain higher (lower) proportions of cash reserves. 


\subsection{IFRS Adoption}

Historically, legal systems are coupled with factors such as political and economic differences between countries created a wide diversity of accounting systems around the world, which made comparing the financial reports of organizations from different countries a difficult process (SODERSTROM; SUN, 2007). IFRS were set up to improve the comparability, reliability and transparency of the disclosed information (BALL; LI; SHIVAKUMAR, 2015).

The IFRS (International Financial Reporting Standards) are a set of accounting standards issued by the International Accounting Standards Board (IASB). The objective of IASB is to provide a set of standards that would ideally apply in the financial statements of all companies in the world (BALL, 2006). In Brazil, Law 11638/2007 partially implemented the International Financial Reporting Standards (IFRS) in 2008. Thus, after the initial transition period, the full set of IFRS was mandatory in the $4^{\text {th }}$ quarter of 2010 . As a result, the international standards have become mandatory for consolidated and individual financial statements of public companies (SANTOS; PONTE; MAPURUNGA, 2014).

The mission of the IFRS Foundation (2017) with the adoption of the standards is to develop a set of international standards that benefit users with more transparent information on more efficient financial markets. Likewise, it is expected that informational asymmetry and the comparability of financial information between organizations in different countries will be reduced facilitating, therefore, the information analysis by users, contributing to economic efficiency in the allocation of scarce resources (BALL; LI; SHIVAKUMAR, 2015).

In addition, other possible IFRS benefit found in the literature is the reduction of international investment barriers with more liquid and efficient markets (BROWN, 2013). The improvement in financial statements' quality would occur due to the use of recognition and measurement criteria that better reflected the reality of the firms, as well as the provision of information in financial footnotes (DASKE, 2006; LOURENÇO; BRANCO, 2015).

Thus, with the adoption of IFRS, we expect more accurate financial information, complete and transparent. In the same way, by eliminating many international differences in accounting standards and standardizing financial reporting, we expect financial statements to be internationally comparable. IFRS can reduce the costs for investors to process financial information, which would increase the capital markets efficiency (BALL, 2006).

We expect a reduction of informational asymmetry, as well as conflicts from agency problems, which could even reduce third-party capital costs (BALL, 2006). Because of this, we expect that the effects of IFRS adoption will also influence the cash holdings of Brazilian public firms, judging by all the possible benefits of adopting them.

Considering all these points, our second research hypothesis is:

H2. The IFRS adoption reduce the percentage of firm's cash holdings.

\section{RESEARCH METHODOLOGY}

We used in this study data of 219 Brazilian companies listed on the "Brasil, Bolsa, Balcão" or B3, in exception of financial institutions. Firms' information were obtained through the Economática ${ }^{\circledR}$ Database and updated by the National Wide Consumer Price Index (Índice Nacional de Preços ao Consumidor Amplo - IPCA) to control inflation distortion, in a manner that the final research sample was composed according to the availability of data from 2000 to 2017. We opt to use the IPCA as an index in our study, given that it is the official index of Brazilian inflation to be applied in the financial statements since 1995 (MARTINS, 2005) corresponding to $209.50 \%$ in this period.

The option of choosing the year 2000 as the initial occurred in order to cover the longest period possible. Furthermore, if previous data were included, the results obtained could be 
distorted due to the large oscillations suffered by the Brazilian economy before this period. Thus, we used the regression model with an unbalanced panel, with a sample of 261 organizations, making an initial number of 3,218 observations with a panel data of 18 years, according to Table 1 . However, among these firms, 219 presented all the required data for the construction of the model. After that, we also removed the observations (232) that presented negative Equity, following Bigelli and Sánchez-Vidal (2012) and Manoel et al. (2017) recommendations. Our final sample is composed of 219 firms in a total of 2,601 firm-year observations.

Table 1. Research Sample

\begin{tabular}{lrr}
\hline \multicolumn{1}{c}{$\mathbf{2 0 0 0 - 2 0 1 7}$} & Firms & Observations \\
\hline Total & $\mathbf{2 6 1}$ & $\mathbf{3 , 2 1 8}$ \\
(-) Companies with missing values for the variables used & 42 & $(385)$ \\
(-) Companies with negative Equity & & $(232)$ \\
\hline (=) Final sample for analysis & $\mathbf{2 1 9}$ & $\mathbf{2 , 6 0 1}$ \\
\hline
\end{tabular}

Finally, the continuous variables were winsorized at their $1^{\text {st }}$ and $99^{\text {th }}$ percentiles to avoid possible influence of the outliers on our results (MANOEL et al., 2018).

\subsection{Description of the Variables}

We present the variables used in the proposed model in sequence.

\subsubsection{Dependent Variable}

We obtain the dependent variable of this study, following the articles of Opler et al. (1999), by calculating the natural logarithm of the sum of cash and cash equivalents divided by total net assets (total assets subtracted from cash and cash equivalents).

\subsubsection{Financial Restriction Criteria}

The form of classification between restricted and unrestricted firms was one of the most controversial topics found in the international literature, see the discussions held by Fazzari, Hubbard and Petersen (1988), Kadapakkam, Kumar and Riddick (1998), Hadlock and Pierce (2010) and Farre-Mensa and Ljungqvist (2016). Therefore, respond whether an organization is restricted or not demand a method with reasonable accuracy.

Since the financial constraints faced by a company cannot be directly observed, studies in the area rely on indirect proxies such as credit rating, dividends payment and criteria related to size, age and leverage (FARRE-MENSA; LJUNGQVIST, 2016). However, since the paper of Fazzari, Hubbard and Petersen (1988), the most traditional method used in the literature is to categorize firms into groups according to their degrees of restriction, from the highest to the lowest degree of constraint. Thus, in order to test the impact of financial constraint on cash levels we use three criteria: Dividends, Size and the Age of the firm.

Han and Qiu (2007) used Dividends and Size. The third, on the other hand, we have chosen to test in this research given the theoretical assumptions presented by Beck et al. (2006) and Hadlock and Pierce (2010).

Dividends: Fazzari, Hubbard and Petersen (1988) suggest the inclusion of the variable dividends, since firms that pay no dividends are more likely to be financially constrained. In this sense, like Opler et al. (1999) we include in the model a dummy variable set equal to one in years where a firm pays dividends, and 0 otherwise. Firms are assigned as financially constrained if there was no dividends paid during the year. 
Size: to distinguish between financially restricted and unrestricted organizations we also use firm size, as Kadapakkam, Kumar and Riddick (1998), Almeida, Campello and Weisbach (2004), Denis and Sibilkov (2010) and Hadlock and Pierce (2010). This proxy is a good observable measure of financial constraints, with smaller companies usually less known, younger and, consequently, more vulnerable to capital market imperfections.

So, for each year we calculate the natural logarithm of total assets, and firms in bottom quartile were classified as restricted, and the firms in top quartile, unconstrained (HAN; QIU, 2007). For size we use two dummies, where we assign the value 1 when the firm is in the $4^{\text {th }}$ quartile, and 0 otherwise (more constrained). The second dummy, on the other hand, assumes 1 when the firm is in the higher quartile, and otherwise 0 .

Age: according to Easley and O'hara (2004), the life cycle of an organization can affects its cash management. Lyandres (2007) also mentions that older companies are already established in the market and have a lower degree of informational asymmetry, as well as incurring lower financing costs than younger firms. In this sense, Hadlock and Pierce (2010) show that the age of firms in addition to size, proxy widely used in the literature to capture financial constraint is also closely related. Nevertheless, the authors mention that size and age are less endogenous than the other restriction criteria.

We chose to use age as a third proxy for financial constraint. We use two dummy variables, where the firms in the lower quartile of age, for each year, were classified as restricted, and those in higher quartile, unrestricted.

IFRS Dummy Variable: we used the IFRS dummy variable to seek evidence about the changes caused by mandatory adoption of Brazilian public firms to the International Accounting Standards. We assign 1 from 2010 (beginning of the second Brazilian phase of adoption of IFRS with full mandatory standards) and 0 before that.

We expected that the adoption of International Financial Reporting Standards coupled with enforcement mechanisms result in financial statements with better quality, comparability and reliability, resulting in lower levels of cash balance.

\subsubsection{Control Variables}

In addition to the aforementioned variables, the literature identify several factors that determine the cash management of firms: Leverage, Growth Opportunities, Profitability (Return on Asset - ROA), Current Liquidity, Net Working Capital, Short-Term Debt and Financial Crisis. The use of these determinants was done in this paper in order to broaden the understanding on the cash levels of Brazilian organizations and to explicitly consider the endogeneity issue that can also arise due to the omission of variables (WOOLDRIDGE, 2013), as suggested and employed in the literature, see Opler et al. (1999), Almeida, Campello and Weisbach (2004), Han and Qiu (2007), Bigelli and Sánchez-Vidal (2012), Manoel et al. (2017) and Manoel et al. (2018).

We did not controlled firms by industry, given the limited number of companies in each industry. The variables Size and Age used to split the dataset between restricted and unrestricted firms were also used as control variables. The use of these variables as control, in turn, occurred without the use of dummies in case of belonging to the first or last quartile, in a manner that they were obtained through the natural logarithm of Size and Age, respectively.

\subsection{Econometric Model}

According to Ozkan and Ozkan (2004), the question of endogeneity in the context of studies about cash holdings is important for several reasons. First, the authors mention that, it is highly likely that observable and unobservable shocks that affect firms' cash reserves can also affect some of the firm-specific characteristics, like leverage, liquidity and dividend payout. In 
other words, the cash holdings decision is contemporaneous with other corporate policies (AMESS; BANERJI; LAMPOUSIS, 2015). Second, Ozkan and Ozkan (2004) state the potential issue about causality direction between cash holdings and their determinants.

To address these issues, we used the Generalized Method of Moments (GMM) estimate for dynamic panel data to address the issue of endogeneity. The GMM method, according to Ozkan and Ozkan (2004), provides consistent parameter estimates. For that, this method uses instruments that can be obtained from the orthogonality conditions that exist between the lagged values of the variables and disturbances (OZKAN; OZKAN, 2004).

Equation 1.

In this way, the econometric model proposed in this research can be observed in

$$
\begin{aligned}
\text { CASH }_{i t}=\beta_{0} & \left.+\beta_{1} \text { CASH }_{i, t-1}+\beta_{2} \text { Div }_{i, t}+\beta_{3} \text { Restricted }_{(\text {Size }}\right)_{i, t} \\
& +\beta_{4} \text { Unrestricted }(\text { Size })_{i, t}+\beta_{5}{\text { Restricted }(\text { Age })_{i, t}} \\
& +\beta_{6}{\text { Unrestricted }(\text { Age })_{i, t}+\beta_{7} \text { IFRS }_{i, t}+\beta_{8} \text { Size }_{i, t}+\beta_{9} \text { Age }}_{i, t} \\
& +\beta_{10} \text { Lev }_{i, t}+\beta_{11} \text { GO }_{i, t}+\beta_{12} \text { ROA }_{i, t}+\beta_{13} C L_{i, t}+\beta_{14} N W C_{i, t} \\
& +\beta_{15} \text { STD }_{i, t}+\beta_{16} \text { Crisis }_{i, t}+u_{i, t}
\end{aligned}
$$

\begin{tabular}{|c|c|c|c|c|}
\hline Variables & Abbreviation & Operational Definition & $\begin{array}{c}\text { Expected } \\
\text { Result }\end{array}$ & Authors \\
\hline Cash Holdings & Cash & Natural log of (Cash/Net Assets) & N/A & Opler et al. (1999) and Manoel et al. (2017) \\
\hline Dividends & Div & $\begin{array}{c}\text { If the firm paid a dividend in the } \\
\text { year }=1 ; \text { Otherwise }=0\end{array}$ & - & Opler et al. (1999) \\
\hline $\begin{array}{l}\text { Restricted } \\
\quad \text { (Size) }\end{array}$ & $\begin{array}{l}\text { Restricted } \\
\quad(\text { Size })\end{array}$ & $\begin{array}{l}\text { Dummy (Company belonging to } \\
\text { the 1st Quartile = } 1 ; \text { Otherwise = } \\
0)\end{array}$ & + & $\begin{array}{c}\text { Han e Qiu (2007) and Kirch, Procianoy } \\
\text { and Terra (2014) }\end{array}$ \\
\hline $\begin{array}{l}\text { Unrestricted } \\
\text { (Size) }\end{array}$ & $\begin{array}{l}\text { Unrestricted } \\
\text { (Size) }\end{array}$ & $\begin{array}{l}\text { Dummy (Company belonging to } \\
\text { 4th Quartile = } 1 \text {; Otherwise }=0 \text { ) }\end{array}$ & - & $\begin{array}{c}\text { Han and Qiu (2007) and Kirch, Procianoy } \\
\text { and Terra (2014) }\end{array}$ \\
\hline $\begin{array}{l}\text { Restricted } \\
\text { (Age) }\end{array}$ & $\begin{array}{l}\text { Restricted } \\
\quad(\text { Age })\end{array}$ & $\begin{array}{l}\text { Dummy (Company belonging to } \\
\text { the } 1 \mathrm{st}=1 ; \text { Otherwise }=0)\end{array}$ & + & N/A \\
\hline $\begin{array}{l}\text { Unrestricted } \\
\text { (Age) }\end{array}$ & $\begin{array}{l}\text { Unrestricted } \\
\text { (Age) }\end{array}$ & $\begin{array}{l}\text { Dummy (Company belonging to } \\
\text { 4th Quartile = } 1 ; \text { Otherwise }=0 \text { ) }\end{array}$ & - & N/A \\
\hline Dummy IFRS & IFRS & $\begin{array}{c}\text { Dummy }(\text { From the year } 2010= \\
1 ; \text { Before } 2010=0)\end{array}$ & - & N/A \\
\hline Size & Size & $\begin{array}{l}\text { Natural logarithm of Total } \\
\text { Assets }\end{array}$ & - & $\begin{array}{l}\text { Han and Qiu (2007), Bigelli and Sánchez- } \\
\text { Vidal (2012) and Chen et al. (2012) }\end{array}$ \\
\hline Age & Age & $\begin{array}{l}\text { Natural logarithm of the firm's } \\
\text { years of life }\end{array}$ & - & $\begin{array}{l}\text { Bigelli and Sánchez-Vidal (2012) and } \\
\text { Manoel et al. (2017) }\end{array}$ \\
\hline Leverage & Lev & $\begin{array}{l}\text { (Total Short-Term Debts + Total } \\
\text { Long-Term Debt)/Net Assets }\end{array}$ & $-/+$ & $\begin{array}{c}\text { Bigelli and Sánchez-Vidal (2012) and } \\
\text { Manoel et al. (2017) }\end{array}$ \\
\hline $\begin{array}{c}\text { Growth } \\
\text { Opportunities }\end{array}$ & GO & $\begin{array}{l}\text { Year-over-Year percentage } \\
\text { Growth in Revenues }\end{array}$ & + & Bigelli and Sánchez-Vidal (2012) \\
\hline $\begin{array}{l}\text { Return on } \\
\text { Assets }\end{array}$ & ROA & Net Income/Total Assets & + & Luo (2011) and Chen et al. (2012) \\
\hline $\begin{array}{c}\text { Current } \\
\text { Liquidity }\end{array}$ & CL & $\begin{array}{c}\text { Current Assets/Current } \\
\text { Liabilities } \\
\end{array}$ & - & $\begin{array}{l}\text { Ferreira and Vilela (2004), Ozkan and } \\
\text { Ozkan (2004) and Manoel et al. (2017) }\end{array}$ \\
\hline $\begin{array}{l}\text { Net Working } \\
\text { Capital }\end{array}$ & NWC & $\begin{array}{l}\text { (Non-Cash Current Assets - } \\
\text { Current Liabilities)/Net Assets }\end{array}$ & - & Opler et al. (1999) \\
\hline $\begin{array}{l}\text { Short-Term } \\
\text { Debt }\end{array}$ & STD & $\begin{array}{c}\text { Total Short-Term Debts/Total } \\
\text { Assets }\end{array}$ & - & Almeida, Campello and Weisbach (2004) \\
\hline $\begin{array}{l}\text { Financial } \\
\text { Crisis }\end{array}$ & Crisis & $\begin{array}{l}\text { Dummy (Years of } 2008 \text { and } \\
2009=1 ; \text { Otherwise }=0)\end{array}$ & + & $\begin{array}{c}\text { Dahroug and Saito (2013) and Manoel et } \\
\text { al. (2017) }\end{array}$ \\
\hline
\end{tabular}

Table 1, in turn, presents the operational definition, the expected result for these variables and the authors who used them.

Table 1. Variables 


\section{RESULTS}

Table 2 presents the Descriptive Statistics of this article. It reveals that the mean cash ratio (Cash/Total Assets) is $10.83 \%$ and the median value is $7.55 \%$.

Table 2. Descriptive Statistics

\begin{tabular}{lccccc}
\hline \multicolumn{1}{c}{ Variable } & Mean & Minimum & Maximum & Median & $\begin{array}{c}\text { Standard } \\
\text { Deviation }\end{array}$ \\
\hline Cash/Total Assets & 0.108 & 0.000 & 0.839 & 0.075 & 0.114 \\
Dividends & -0.438 & -6.277 & 2.063 & -0.268 & 0.937 \\
Restricted (Size) & 0.253 & 0.000 & 1.000 & 0.000 & 0.435 \\
Unrestricted (Size) & 0.253 & 0.000 & 1.000 & 0.000 & 0.435 \\
Restricted (Age) & 0.256 & 0.000 & 1.000 & 0.000 & 0.437 \\
Unrestricted (Age) & 0.256 & 0.000 & 1.000 & 0.000 & 0.437 \\
IFRS & 0.575 & 0.000 & 1.000 & 1.000 & 0.494 \\
Size & 15.073 & 11.380 & 19.648 & 14.991 & 1.710 \\
Age & 3.745 & 1.386 & 4.963 & 3.989 & 0.840 \\
Leverage & 0.308 & 0.000 & 0.840 & 0.306 & 0.205 \\
Growth Opportunities & 0.100 & -0.663 & 2.404 & 0.043 & 0.393 \\
ROA & 0.075 & -0.207 & 0.386 & 0.069 & 0.087 \\
Current Liquidity & 2.072 & 0.378 & 10.982 & 1.678 & 1.592 \\
Net Working Capital & 0.08 & -0.41 & 0.60 & 0.05 & 0.20 \\
Short-Term Debt & 0.09 & 0.00 & 0.39 & 0.07 & 0.09 \\
Financial Crisis & 0.12 & 0.00 & 1.00 & 0.00 & 0.33 \\
\hline
\end{tabular}

Figure 1 presents in detail the variation of cash levels over the period. We verified through this figure that the highest average in cash occurred in the period between 2007 and 2009. This fact reinforces the assumptions found in the literature regarding the effects of the subprime crisis on the cash balances, since the organizations of our sample maintained higher percentages in this period.

\section{Figure 1. Variation of Cash Holdings}

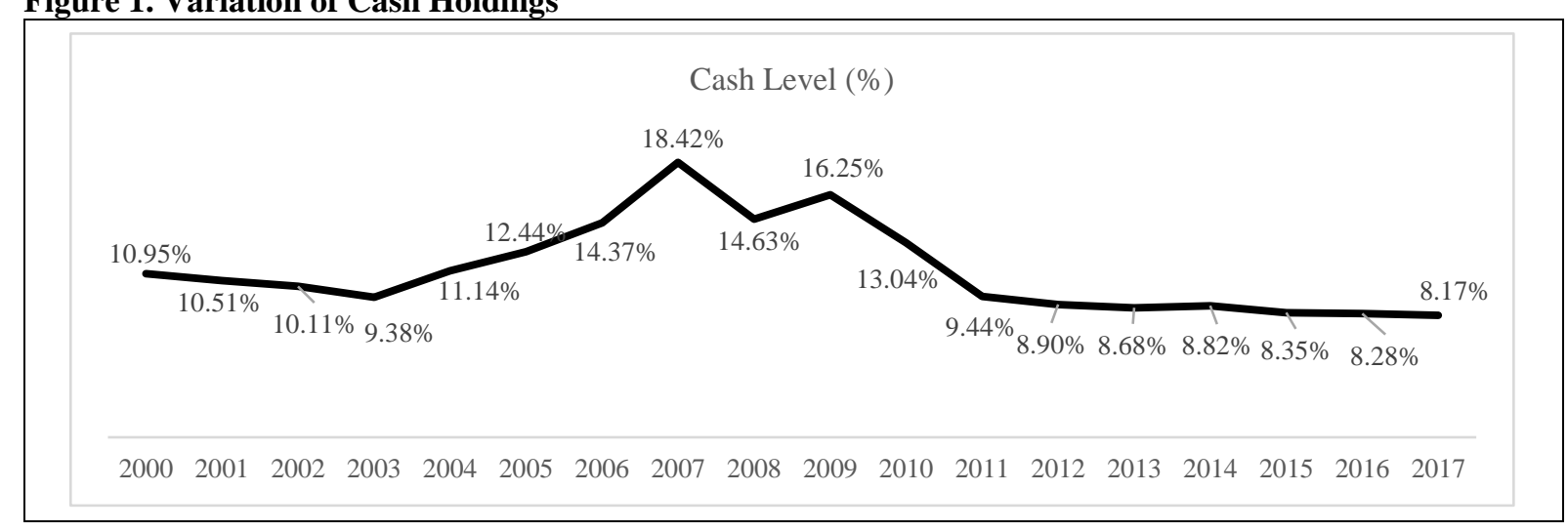

Bates, Kahle and Stulz (2009), for example, document an increase in the cash holdings of U.S. industrial firms from 1980 to 2006. In this sense, we observe in Figure 1 that Brazilian public companies have tended to reduce their average cash levels in recent years, especially after 2010. This initial evidence suggests that the average cash holdings of Brazilian firms appears to have decreased after the IFRS adoption in Brazil.

When separating the companies by the Financial Restriction criteria (Table 3), in order to verify the variation of the Cash Levels (Cash and Cash Equivalents/Total Assets), we verified that organizations with distributed dividends, $78.62 \%$ of the sample, reserved a greater part of 
their total assets in Cash and Equivalents (11.89\%), when compared to the rest that did not distribute dividends, which presented an average level of $6.94 \%$, representing $21.38 \%$ of the sample used.

In relation to Size and Age, we found that those classified in the group as restricted maintained a higher percentage of their assets in cash than those in the unrestricted group. Given that the normal distribution is rejected for the distribution between mean cash/total assets, the median is a better measure of central tendency (PINKOWITZ; STULZ; WILLIAMSON, 2007). So, non-tabulated results from the median difference test (Wilcoxon test) indicated that medians were statistically significant at the $1 \%$ level among the constrained and unconstrained groups only for size and dividend criteria. Thus, we do not reject the first research hypothesis, since that our results indicate that companies classified as financially constrained by size criteria and that distributed dividends tend to hold more cash.

Table 3. Mean of Cash Reserves for each Financial Constraints Proxies

\begin{tabular}{|c|c|c|c|}
\hline Proxy & Measure & Cash Level & Observations \\
\hline \multirow{5}{*}{ Restricted (Dividends) } & Mean & $6.94 \%$ & \multirow{5}{*}{556} \\
\hline & Median & $3.75 \%$ & \\
\hline & Standard Deviation & 0.097 & \\
\hline & Minimum & $0.01 \%$ & \\
\hline & Maximum & $78.96 \%$ & \\
\hline \multirow{5}{*}{ Unrestricted (Dividends) } & Mean & $11.89 \%$ & \multirow{5}{*}{2045} \\
\hline & Median & $8.97 \%$ & \\
\hline & Standard Deviation & 0.1156 & \\
\hline & Minimum & $0.01 \%$ & \\
\hline & Maximum & $83.88 \%$ & \\
\hline \multirow{5}{*}{ Restricted (Size) } & Mean & $11.74 \%$ & \multirow{5}{*}{657} \\
\hline & Median & $6.09 \%$ & \\
\hline & Standard Deviation & 0.146 & \\
\hline & Minimum & $0.01 \%$ & \\
\hline & Maximum & $83.88 \%$ & \\
\hline \multirow{5}{*}{ Unrestricted (Size) } & Mean & $9.55 \%$ & \multirow{5}{*}{657} \\
\hline & Median & $7.79 \%$ & \\
\hline & Standard Deviation & 0.077 & \\
\hline & Minimum & $0.03 \%$ & \\
\hline & Maximum & $45.61 \%$ & \\
\hline \multirow{5}{*}{ Restricted (Age) } & Mean & $11.27 \%$ & \multirow{5}{*}{667} \\
\hline & Median & $8.00 \%$ & \\
\hline & Standard Deviation & 0.121 & \\
\hline & Minimum & $0.02 \%$ & \\
\hline & Maximum & $83.88 \%$ & \\
\hline \multirow{5}{*}{ Unrestricted (Age) } & Mean & $9.74 \%$ & \multirow{5}{*}{666} \\
\hline & Median & $7.02 \%$ & \\
\hline & Standard Deviation & 0.091 & \\
\hline & Minimum & $0.01 \%$ & \\
\hline & Maximum & $47.54 \%$ & \\
\hline
\end{tabular}


Furthermore, we observed a low percentage of the assets allocated in cash, independent of the group analyzed. In this sense, Lozano and Caltabiano (2014) provide evidence that in Brazil there is a tendency to pay dividends in order to build a good reputation in the Brazilian stock market. Thus, instead of maintaining large percentages of the cash flows generated, managers choose to distribute larger dividends.

In addition, it is expected that in countries with low shareholder protection, there will be a greater distribution of dividends, so that the evidence obtained by Pinkowitz, Stulz and Williamson (2007) still suggest that the distribution of a larger percentage of the resources generated, rather than the maintenance in cash, generates greater value for the company. This fact occurs, according to the authors, since the shareholders feel safer with money in their hands than under the care of managers, given the agency problems related to maintaining higher cash holdings.

Finally, Denis and Sibilkov (2010) point out possible explanations for this intriguing behavior, such as the limitation of larger reserves by the board of directors due to possible opportunistic actions of the agent; the routine waste of cash; and the poor financial performance of organizations, since this condition may have caused firms to have used its previous cash reserves so that it has not yet been able to rebuild its reserves properly.

After the analysis of the descriptive statistics, we verified the normality of the variables of the model using Shapiro-Wilk test, we found that they did not present a normal distribution. In addition, the results obtained through the normality test of the residues also indicated nonnormality. The lack of normality is a common factor in accounting and financial researches (FÁVERO, 2015). We attribute part of this result to the use of a non-random sample.

Table 4. Generalized Method of Moments cash holdings regression

\begin{tabular}{|c|c|c|c|}
\hline Variables & Coefficients & $\mathbf{Z}$ & P-value \\
\hline Cash $_{\mathrm{t}-1}$ (instrumental variable) & 0.335 & 10.730 & $0.000 * * *$ \\
\hline Constant & -0.009 & -0.790 & 0.429 \\
\hline Dividends & 0.210 & 3.167 & $0.001 * * *$ \\
\hline Restricted (Size) & 0.219 & 2.008 & $0.044 * *$ \\
\hline Unrestricted (Size) & -0.207 & -1.571 & 0.116 \\
\hline Restricted (Age) & -0.335 & -2.089 & $\mathbf{0 . 0 3 6} * *$ \\
\hline Unrestricted (Age) & 0.184 & 1.063 & 0.287 \\
\hline IFRS & -0.272 & -2.999 & $0.002 * * *$ \\
\hline Size & 0.096 & 1.155 & 0.247 \\
\hline Age & -0.277 & -1.009 & 0.312 \\
\hline Leverage & 2.482 & 9.953 & $0.000 * * *$ \\
\hline Growth Opportunities & 0.108 & 1.846 & $0.064 *$ \\
\hline ROA & 1.107 & 3.082 & $0.002 * * *$ \\
\hline Current Liquidity & 0.321 & 12.300 & $0.000 * * *$ \\
\hline Net Working Capital & -4.396 & -17.420 & $0.000 * * *$ \\
\hline Short-Term Debt & -4.426 & -9.537 & $0.000 * * *$ \\
\hline Financial Crisis & -0.028 & -0.360 & 0.718 \\
\hline Observations $(n)$ & & \multicolumn{2}{|c|}{2,072} \\
\hline $\operatorname{Corr}(y, \widehat{y})$ & & \multicolumn{2}{|c|}{0.6538} \\
\hline Sargan test (df) & & \multicolumn{2}{|c|}{208.381 (135) with P-value (0.000) } \\
\hline
\end{tabular}

Notes: * Statistically significant at $10 \% ; * *$ statistically significant at 5\%; *** statistically significant at $1 \%$.

Then, we conducted the Variance Inflation Factor (VIF) test, in which we verified that no value was above 10 , which could indicate problems related to multicollinearity (FÁVERO, 2015). The highest coefficient obtained was for Size (5.603), which can happen due to its use 
as a criterion of financial restriction. In sequence, we analyze the heteroskedasticity of the model, using the White test, we reject the null hypothesis when verifying that the model presented heteroskedasticity problem. To address this problem, we used of robust regressions with standard asymptotic errors, given its better adjust to treat data with heteroscedasticity problems (FÁVERO, 2015).

Table 4 presents the results obtained by the GMM estimate for dynamic panel data with standard asymptotic errors.

Amess, Banerji and Lampousis (2015) state that the usual problem in implementing the GMM model is finding an appropriate instrument that is correlated with the endogenous variable but is uncorrelated with the error term. In this way, the results of the Sargan test (Table 4) indicate that the instrument variable ( $\mathrm{Cash}_{\mathrm{t}-1}$ ) has no correlation with the error term.

We verify that dividend-paying companies hold more cash than non-dividend paying firms. Ozkan and Ozkan (2004) attributes this positive association between cash and dividends, since that dividend-paying companies can hold more cash to avoid a situation in which they are short of cash holdings to support their dividend payments. Although contradictory, Al-Najjar (2013) also obtained a positive association between the dividend payout ratio and cash for its sub-sample of Brazilian companies.

Furthermore, we found that firms classified as financially constrained by size criteria tend to hold more cash than the unconstrained firms. Firms restricted by age, on the other hand, presented a negative sign at the 5\% level. These results corroborate the evidence obtained in the descriptive statistics, since we observed that the differences between the medians of the financially restricted and unrestricted groups by age criteria were not significant. Thus, our study provides evidence that age, given the limitations of our study, does not appear to be a robust criteria to classify firms into constrained and unconstrained.

Regarding the adoption of the International Financial Reporting Standards (IFRS), we verify that the IFRS dummy had a negative association at the $1 \%$ level, which represents a reduction in the levels of cash held after the mandatory adoption of the IFRS. Consequently, we do not reject the second research hypothesis, since the result is in line with the flagged by articles on the subject, given that with the adoption of the international standards, users are expected to benefit from more comparable, transparent and higher-quality information, thus reducing problems related to information asymmetry and agency conflicts (AHMED; CHALMERS; KHLIF, 2013).

However, the adoption of IFRS by itself may not represent all this variation, indicating, for example, that other factors, such as issues related to the legal and political system and enforcement mechanisms, also influence this reduction in cash levels. In this sense, the adoption of a new set of standards is only one of the determinants of the quality of accounting information.

The mixed results found in the literature on the consequences of the adoption of IFRS around the world, for example in improving the quality and comparability of financial and accounting information, reduction in agency costs and informational asymmetry are also linked to the other factors cited by Soderstrom and Sun (2007) in their work, such as the legal and political system and the incentives for disclosure. What does not preclude, however, that the methodological characteristics of this work also influence the conflicting results in the literature.

Thus, the motivations underlying the adoption of IFRS are also relevant, since some companies can make the changes to the norms only as a title, in a way that no to strengthen its commitment to transparency and not to make significant changes in its communication material with the market (DASKE et al., 2013). 
Table 5. Generalized Method of Moments cash holdings regression by financial constrained criteria

\begin{tabular}{|c|c|c|c|c|c|c|c|c|c|c|c|c|}
\hline \multirow[b]{3}{*}{ Variables } & \multicolumn{4}{|c|}{ Dividends } & \multicolumn{4}{|c|}{ Size } & \multicolumn{4}{|c|}{ Age } \\
\hline & \multicolumn{2}{|c|}{ Constrained } & \multicolumn{2}{|c|}{ Unconstrained } & \multicolumn{2}{|c|}{ Constrained } & \multicolumn{2}{|c|}{ Unconstrained } & \multicolumn{2}{|c|}{ Constrained } & \multicolumn{2}{|c|}{ Unconstrained } \\
\hline & Coefficients & P-value & Coefficients & P-value & Coefficients & P-value & Coefficients & P-value & Coefficients & P-value & Coefficients & P-value \\
\hline $\operatorname{Cash}_{\mathrm{t}-1}$ & 0.154 & $0.033 * *$ & 0.332 & $0.000 * * *$ & 0.276 & $0.000 * * *$ & 0.306 & $0.000 * * *$ & 0.361 & $0.000 * * *$ & 0.226 & $0.000 * * *$ \\
\hline Constant & -0.102 & $0.063 *$ & 0.003 & 0.814 & -0.067 & $0.025 * *$ & -0.006 & 0.708 & -0.011 & 0.804 & 0.007 & 0.891 \\
\hline Dividends & - & - & - & - & 0.261 & $0.055 *$ & -0.058 & 0.631 & 0.051 & 0.704 & 0.442 & $0.001 * * *$ \\
\hline IFRS & -0.329 & 0.253 & -0.227 & $0.018 * *$ & -0.045 & 0.838 & -0.118 & 0.371 & -0.117 & 0.612 & -0.328 & $0.083 *$ \\
\hline Size & -0.079 & 0.711 & -0.076 & 0.403 & 0.074 & 0.704 & 0.362 & $0.017 * *$ & -0.097 & 0.460 & -0.048 & 0.791 \\
\hline Age & 1.166 & 0.164 & -0.070 & 0.837 & 0.832 & 0.390 & -0.251 & 0.510 & -0.137 & 0.800 & 3.607 & 0.536 \\
\hline Leverage & 1.753 & $0.008 * * *$ & 2.559 & $\mathbf{0 . 0 0 0} * * *$ & 1.725 & $0.006 * * *$ & 2.127 & $0.000 * * *$ & 3.281 & $0.000 * * *$ & 2.214 & $0.000 * * *$ \\
\hline Growth Opport. & 0.345 & $0.015 * *$ & -0.041 & 0.571 & 0.285 & 0.135 & -0.151 & 0.182 & 0.080 & 0.414 & -0.143 & 0.270 \\
\hline ROA & -0.198 & 0.819 & 1.837 & $0.000 * * *$ & 0.284 & 0.665 & 3.206 & $0.000 * * *$ & 2.340 & $0.002 * * *$ & 1.680 & $0.021 * *$ \\
\hline Current Liquidity & 0.377 & $0.000 * * *$ & 0.349 & $0.000 * * *$ & 0.307 & $0.000 * * *$ & 1.044 & $0.000 * * *$ & 0.279 & $0.000 * * *$ & 0.292 & $0.000 * * *$ \\
\hline Net Work. Capital & -2.471 & $0.000 * * *$ & -5.037 & $0.000 * * *$ & -3.062 & $\mathbf{0 . 0 0 0} * * *$ & -6.686 & $0.000 * * *$ & -3.464 & $0.000 * * *$ & -4.044 & $0.000 * * *$ \\
\hline Short-Term Debt & -2.761 & $0.017 * *$ & -3.972 & $0.000 * * *$ & -0.740 & 0.505 & -3.262 & $0.000 * * *$ & -3.882 & $0.000 * * *$ & -3.714 & $0.000 * * *$ \\
\hline Financial Crisis & -0.072 & 0.805 & 0.012 & 0.878 & 0.439 & $0.042 * *$ & 0.125 & 0.274 & -0.037 & 0.849 & 0.078 & 0.645 \\
\hline Observations (n) & \multicolumn{2}{|c|}{222} & \multicolumn{2}{|c|}{1,505} & \multicolumn{2}{|c|}{422} & \multicolumn{2}{|c|}{511} & \multicolumn{2}{|c|}{471} & \multicolumn{2}{|c|}{525} \\
\hline $\operatorname{Corr}(y, \widehat{y})$ & \multicolumn{2}{|c|}{0.6077} & \multicolumn{2}{|l|}{0.6592} & \multicolumn{2}{|c|}{0.6811} & \multicolumn{2}{|c|}{0.6447} & \multicolumn{2}{|c|}{0.6420} & \multicolumn{2}{|c|}{0.6141} \\
\hline Sargan test (df) & \multicolumn{2}{|c|}{$\begin{array}{c}131.74(106) \\
\text { P-value }(0.000)\end{array}$} & \multicolumn{2}{|c|}{$\begin{array}{c}207.95(135) \\
\text { P-value }(0.000)\end{array}$} & \multicolumn{2}{|c|}{$\begin{array}{c}202.16(128) \\
\text { P-value }(0.000)\end{array}$} & \multicolumn{2}{|c|}{$\begin{array}{c}236.58(135) \\
\text { P-value }(0.000)\end{array}$} & \multicolumn{2}{|c|}{$\begin{array}{c}170.84(135) \\
\text { P-value }(0.000)\end{array}$} & \multicolumn{2}{|c|}{$\begin{array}{c}225.84(135) \\
\text { P-value }(0.000)\end{array}$} \\
\hline
\end{tabular}

Notes: $*$ Statistically significant at $10 \% ; * *$ statistically significant at $5 \% ; * * *$ statistically significant at $1 \%$. 
Regarding the control variables, we verify that the coefficients of them are mostly consistent with prior findings. The effect of growth opportunities on cash holdings is positive and significant at $10 \%$. This result is consistent with the fact that organizations with greater growth opportunities accumulate more cash to minimize the opportunity costs of foregone investment. In the case of the variable of profitability (ROA) used, we verified that more profitable firms tend to hold more cash. Our results, therefore, support the results of Bigelli and Sanchez-Vidal (2012) and Hall, Mateus and Mateus (2014).

Firms with higher leverage levels are more likely to experience problems with financial distress (OZKAN; OZKAN, 2004; AL-NAJJAR, 2013). Our evidence, consequently, are consistent with the fact that firms with higher leverage levels maintain higher cash levels to decrease the probability of financial distress. The current assets can be easily converted into cash holdings (OPLER et al., 1999). Thus, we obtained a negative and significant association between net working capital and Cash.

In the same way, the cost of converting non-cash liquid assets into cash reserves is lower than the cost of converting other assets (OZKAN; OZKAN, 2004; AL-NAJJAR, 2013). However, our evidence points to a positive and significant association at the $1 \%$ level between current liquidity and cash. The short-term debt variable, in the same way, also presented a coefficient contrary to the expected. Finally, the variables size, age and financial crisis were not statistically significant in the model.

When we splitted the sample by the restriction criteria used, we verified that in general, the estimated coefficients are in line with those reported in Table 4. One of the few differences in the results was the fact that the variable financial crisis presented a positive statistical significance at the $1 \%$ level only in the group constrained by Size criteria. It seems that larger firms increased their average cash level as a precaution, aiming to overcome the adverse conditions of this period. Overall, the determinants of cash holdings seems to be similar to both financially constrained and unconstrained firms.

\section{CONCLUSION}

Our results demonstrate that the decision to keep larger or smaller cash holdings by Brazilian public companies is impacted by the level of financial constraint of each company. Especially when it comes to aspects of size and age, we observed that larger companies maintain lower cash levels than the smaller ones. In relation to the dividend dummy, we found that those who distributed dividends reserved a larger share of their assets in cash. Finally, the results of this study demonstrated a reduction in the average cash levels after the IFRS adoption in Brazil.

In addition, we mentioned as a concern the low percentage of assets allocated in cash by Brazilian firms, in which we find a mean (median) of $10.83 \%$ (7.55\%). This concern occurs, since in a context where the literature suggests that firms located in a less developed capital market with greater difficulties in obtaining financing should maintain larger cash balances. We attribute part of the low percentage of assets found in cash to a positive association with the dividend dummy, since the agency problems related to the maintenance of larger cash reserves may cause shareholders to prefer the distribution of most of the resources generated instead of its maintenance in cash. Previous evidence still indicates that to attract more investors, the companies listed on the B3 "Brasil, Bolsa, Balcão" may be choosing to pay a higher level of dividends in comparison to other emerging markets, which may be better explored in the future.

Moreover, the firm's weak financial condition may be contributing, since it may be making it impossible for companies to rebuild their cash reserves adequately, in a way that current investments of each company become highly dependent on current cash flows. In this sense, new studies can take advantage of this gap in order to focus on the reasons why Brazilian companies keep low cash balances. 
Furthermore, identifying which organizations are financially constrained is an issue that has been debated in the economic and financial literature, in a manner that there is still no consensus on robust proxies that can capture the financial constraint construct. Thus, the existing results that have been attributed to financial frictions may actually reflect differences in investment and corporate finance policies at different stages of their life cycle. Therefore, new studies can take advantage of this gap in the intention of seeking new proxies for the financial constraint construct in order to broaden the understanding on the subject. In addition, expanding the sample to other countries is also a natural way to be explored in new studies for comparative purposes.

\section{REFERENCES}

AHMED, K.; CHALMERS, K.; KHLIF, H. A Meta-analysis of IFRS Adoption Effects. The International Journal of Accounting, v. 48, n. 2, p. 173-217, 2013.

ALMEIDA, H.; CAMPELLO, M.; WEISBACK, M. S. The Cash Flow Sensitivity of Cash. The Journal of Finance, v. 59, n. 4, p. 1777-1804, 2004.

AMESS, K.; BANERJI, S. LAMPOUSIS, A. Corporate cash holdings: Causes and consequences. International Review of Financial Analysis, v. 42, n. c, p. 421-433, 2015.

BALL, R. International financial reporting standards (IFRS): pros and cons for investors. Accounting and Business Research, v. 36, n. 1, p. 5-27, 2006.

BALL, R.; LI, X.; SHIVAKUMAR, L. Contractibility and transparency of financial statement information prepared under IFRS: Evidence from debt contracts around IFRS adoption.

Journal of Accounting Research, v. 53, n. 3, p. 915-963, 2015.

BATES, T. W.; KAHLE, K. M.; STULZ, R. M. Why do US Firms hold so much more cash than they used to? The Journal of Finance, v. 64, n. 5, p. 1985-2021, 2009.

BAUMOL, W. J. The Transactions Demand for Cash: An Inventory Theoretic Approach. Quarterly Journal of Economics, v. 66, n. 4, p. 545-556, 1952.

BECK, T.; DEMIRGÜÇ-KUNT, A.; LAEVEN, L.; MAKSIMOVIC, V. The determinants of financing obstacles. Journal of International Money and Finance, v. 25, n. 6, p. 932-952, 2006.

BIGELLI, M.; SÁNCHEZ-VIDAL, J. Cash holdings in private firms. Journal of Banking and Finance, v. 36, n. 1, p. 26-35, 2012.

BROWN, P. Some observations on research on the benefits to nations of adopting IFRS. The Japanese Accounting Review, v. 3, p. 1-19, 2013.

CAMPELLO, M. Contemporary corporate finance research on South America. Journal of Corporate Finance, v. 18, n. 4, p. 879-882, 2012.

CAMPELLO, M.; GRAHAM, J. R.; HARVEY, C. R. The real effects of financial constraints: Evidence from a financial crisis. Journal of Financial Economics, v. 97, n. 3, p. 470-487, 2010. 
CASH HOLDINGS IN BRAZIL: A STUDY CONSIDERING THE EFFECTS OF FINANCIAL

CONSTRAINTS AND THE ADOPTION OF INTERNATIONAL FINANCIAL REPORTING STANDARDS

CHEN, Q.; CHEN, X.; SCHIPPER, K.; XU, Y.; XUE, J. The Sensitivity of Corporate Cash Holdings to Corporate Governance. The Review of Financial Studies, v. 25, n. 12, p. 36103644, 2012.

DAHROUGE, F. M.; SAITO, R. Políticas de Cash Holdings: Uma Abordagem Dinâmica das Empresas Brasileiras. Revista Brasileira de Finanças, v. 11, n. 3, p. 343-373, 2013.

DASKE, H. Economic benefits of adopting IFRS or US-GAAP: Have the expected cost of equity capital really decreased? Journal of Business Finance \& Accounting, v. 33, n. 3-4, p. 329-373, 2006.

DASKE, H.; HAIL, L.; LEUZ, C.; VERDI, R. Mandatory IFRS Reporting around the World: Early Evidence on the Economic Consequences. Journal of Accounting Research, v. 46, n. 5, p. 1085-1142, 2008.

DASKE, H.; HAIL, L.; LEUZ, C.; VERDI, R. Adopting a label: heterogeneity in the consequences of IFRS adoptions. Journal of Accounting Research, v. 51, n. 3, p. 495-547, 2013.

DENIS, D. J.; SIBILKOV, V. Financial constraints, investment, and the value of cash holdings. Review of Financial Studies, v. 23, n. 1, p. 247-269, 2010.

DITTMAR, A.; MAHRT-SMITH, J.; SERVAES, H. International Corporate Governance and Corporate Cash Holdings. The Journal of Financial and Quantitative Analysis, v. 38, n. 1, p. 111-133, 2003.

EASLEY, D.; O'HARA, M. Information and the Cost of Capital. The Journal of Finance, v. 59, n. 4, p. 1553-1583, 2004.

FARRE-MENSA, J.; LJUNGQVIST, A. Do measures of financial constraints measure financial constraints? Review of Financial Studies, v. 2, n. 2, p. 271-308, 2016.

FÁVERO, L. P. L. Análise de Dados: Modelos de Regressão com Excel®, Stata e SPSS®. Rio de Janeiro: Elsevier, 2015.

FAZZARI, S. M.; HUBBARD, G. R.; PETERSEN, B. C. Financing Constraints and Corporate Investment. Brookings Papers on Economic Activity, v. 1, n.1, p. 141-195, 1988.

FERREIRA, M. A.; VILELA, A. S. Why do firms hold cash? Evidence from EMU countries. European Financial Management, v. 10, n. 2, p. 295-319, 2004.

GAO, H.; HARFORD, J.; LI, K. Determinants of corporate cash policy: Insights from private firms. Journal of Financial Economics, v. 109, n. 3, p. 623-639, 2013.

HADLOCK, C. J.; PIERCE, J. R. New Evidence on Measuring Financial Constraints: Moving Beyond the KZ Index. The Review of Financial Studies, v. 23, n. 5, p. 1909-1940, 2010.

HALL, T.; MATEUS, C.; MATEUS, I. B. What determines cash holdings at privately held and publicly traded firms? Evidence from 20 emerging markets. International Review of Financial Analysis, v. 33, n. 3, p. 104-116, 2014. 
HAN, S.; QIU, J. Corporate Precautionary Cash Holdings. Journal of Corporate Finance, v. 13, n. 1, p. 43-57, 2007.

HARFORD, J. Corporate Cash Reserves and Acquisitions. The Journal of Finance, v. 54, n. 6, p. 1969-1997, 1999.

IFRS (International Financial Reporting Standards). (2017). Pocket Guide to IFRS $®$ Standards: the global financial reporting language. Disponível em: $<$ http://www.ifrs.org//media/feature/around-the-world/documents/pocket-guide-2017.pdf >. Access in: 24 oct. 2017.

JENSEN, M. C. Agency Costs of Free Cash Flow, Corporate Finance, and Takeovers. The American Economic Review, v. 76, n. 2, p. 323-329, 1986.

JENSEN, M. C.; MECKLING W. H. Theory of the firm: Managerial behavior, agency costs and ownership structure. Journal of Financial Economics, v. 3, n. 4, p. 305-360, 1976.

KADAPAKKAM, P.; KUMAR, P. C.; RIDDICK, L. A. The impact of cash flows and firm size on investment: The international evidence. Journal of Banking \& Finance, v. 22, n. 3, p. 293-320, 1998.

KAPLAN, S. N.; ZINGALES, L. Do Investment-Cash Flow Sensitivities Provide Useful Measures of Financing Constraints? Quarterly Journal of Economics, v. 112, n. 1, p. 169$215,1997$.

KEYNES, J. M. The General Theory of Employment, Interest and Money. London: McMillan, 1936.

KIRCH; G.; PROCIANOY, J. L.; TERRA, P. R. S. Restrições Financeiras e a Decisão de Investimento das Firmas Brasileiras. Revista Brasileira de Economia, v. 68, n. 1, p.103-123, 2014.

LEE, C.; PARK, H. Financial constraints, board governance standards, and corporate cash holdings. Review of Financial Economics, v. 28, n. 1, p. 21-34, 2016.

LÓPEZ-GUTIÉRREZ, C.; SANFILIPPO-AZOFRA, S.; TORRE-OLMO, B. Investment decisions of companies in financial distress. BRQ Business Research Quarterly, v. 18, n. 3, p. 174-187, 2015.

LOURENÇO, I. M. E. C.; BRANCO, M. E. M. de A. D. C. Main consequences of IFRS adoption: Analysis of existing literature and suggestions for further research. Revista Contabilidade \& Finanças, v. 26, n. 68, p. 126-139, 2015.

LOZANO, M. B.; CALTABIANO, S. Cross institutional cash and dividend policies: focusing on Brazilian firms. Applied Economics, v. 47, n. 3, p. 239-254, 2014.

LUO, M. M. A bright side of financial constraints in cash management. Journal of Corporate Finance, v. 17, n. 5, p. 1430-1444, 2011.

LYANDRES, E. Costly external financing, investment timing, and investment-cash flow sensitivity. Journal of Corporate Finance, v. 13, n. 5, p. 959-980, 2007. 
CASH HOLDINGS IN BRAZIL: A STUDY CONSIDERING THE EFFECTS OF FINANCIAL

CONSTRAINTS AND THE ADOPTION OF INTERNATIONAL FINANCIAL REPORTING STANDARDS

MANOEL, A. A. S.; MORAES, M. B. C.; NAGANO, M. S.; SOBREIRO, V. A. Cash holdings and corporate governance: The effects of premium listing in Brazil. Review of Development Finance, v. 8, n. 2, p. 106-115, 2018.

MANOEL, A. A. S.; MORAES, M. B. C.; SANTOS, D. F. L.; NEVES, M. F. Determinants of corporate cash holdings in times of crisis: insights from Brazilian Sugarcane Industry private firms. International Food and Agribusiness Management Review, v. 21, n. 2, p. 201-218, 2017.

MARTINS, E. 2005. Análise crítica de balanços: problemas na análise da estrutura dos balanços no Brasil. Boletim IOB, Temática Contábil e Balanços, v. 4, n. 26, p.1-9, 2005.

MILLER, M. H.; ORR, D. A model of the demand for money by firms. The Quarterly Journal of Economics, v. 80, n. 3, p. 413-435, 1966.

MODIGLIANI, F.; MILLER, M. H. The cost of capital, corporation finance and the theory of investment. The American Economic Review, v. 48, n. 3, p. 261-297, 1958.

MYERS, S. C.; MAJLUF, N. S. Corporate Financing and Investment Decisions When Firms Have Information that Investors do not Have. Journal of Financial Economics, v. 13, n. 2, p. 187-221, 1984.

OPLER, T.; PINKOWITZ, L.; STULZ, R.; WILLIAMSON, R. The determinants and implications of corporate cash holdings. Journal of Financial Economics, v. 52, n. 1, p. 3 46, 1999.

OZKAN, A.; OZKAN, N. Corporate cash holdings: An empirical investigation of UK companies. Journal of Banking \& Finance, v. 28, n. 9, p. 2103-2134, 2004.

PINKOWITZ, L.; STULZ, R. M.; WILLIAMSON, R. Do U.S. Firms Hold More Cash than Foreign Firms Do? The Review of Financial Studies, v. 29, n. 2, p. 309-348, 2016.

PINKOWITZ, L.; WILLIAMSON, R.; STULZ, R. M. Cash holdings, dividend policy, and corporate governance: a cross-country analysis, Journal of Applied Corporate Finance, v. 19, n. 1, p. 81-87, 2007.

SANTOS, E. S.; PONTE, V. M. R.; MAPURUNGA, P. V. R. Mandatory IFRS Adoption in Brazil (2010): Index of Compliance with Disclosure Requirements and some Explanatory Factors of Firms Reporting. Revista Contabilidade \& Finanças, v. 25, n. 65, p. 161-176, 2014.

SODERSTROM, N. S.; SUN, K. J. IFRS adoption and accounting quality: A review. European Accounting Review, v. 16, n. 4, p. 675-702, 2007.

WEIDEMANN, J. F. A state-of-the-art review of corporate cash holding research. Journal of Business Economics, v. 88, n. 6, p. 765-797, 2017.

WOOLDRIDGE, J. M. Introductory econometrics: a modern approach, 5th ed. South Western, Nashville, TN, USA, 2013. 